\title{
Much more than Economy: Assessing electoral Accountability in the CEE Member States
}

\author{
ANDREA FUMAROLA
}

$\frac{\text { DE }}{G}$ DE GRUYTER

Politics in Central Europe (ISSN: 1801-3422)

Vol. 12 , No. 2

DOI: $10.1515 /$ pce-2016-0012

\begin{abstract}
Electoral accountability is considered the mechanism through which voters hold governments responsible for their performance. Questioning the traditional approach of economic voting theory, the article focuses on the influence exerted by the political context-comprehensively considered as government clarity of responsibility, availability of governing alternatives, electoral formula, and freedom of the media-on the accountability mechanism in eleven countries of Central and Eastern Europe. Using individual and aggregate data collected after the 2014 European Elections by the European Election Study (EES), the present article analyses this process in its double dimension of answerability and enforcement (Schedler 1999). Our findings suggest that voters' ability to express discontent with economic performance in new European democracies is strongly influenced by specific characteristics of the political context. A stable and cohesive government as well as a free media system, in particular, seem to facilitate performance voting in the region.
\end{abstract}

Key words: Central-Eastern Europe, electoral accountability, political system, mass media

\section{Introduction}

The wider theme of good democracy has always affected political studies proposing, in the last decades, more and more comprehensive and stimulating approaches to its analysis (Dahl 1971; Lijphart 1999; Morlino 2011). According to the procedural conception of democracy as developed by Schumpeter (1943) and Dahl (1971), elections-considered as a sanctioning or rewarding 
mechanism-are at the heart of any modern democratic system (Powell 2000; Stegmaier 2009). Thus, the concept of electoral accountability inevitably becomes important for understanding what democratic quality is, assuming a relevant role for its analysis.

Schedler (1999) puts forth one of the most comprehensive concepts of accountability, composed of two related features: answerability and enforcement. Answerability refers to the obligation of governments to provide information and justification for a political act or series of acts, while enforcement stands for the sanction, i.e. the consequence the voters draw after evaluating the information, justifications, and other aspects and interests behind the political act. Given these two conditions, citizens in representative democracies hold judgment over their representatives through periodic elections. ${ }^{1}$ In fact, in the absence of answerability, power holders are free to act as they choose, without any checks and balances. In the absence of enforcement, where there are no consequences for failing to provide a satisfactory account, so the process of demanding and providing an account is undermined.

Even though in the last decades electoral accountability has become one of the most studied questions in political science-mostly in the wake of economic voting theory and the clarity of responsibility approach-cross-national studies have generally paid more attention to consolidated democracies (Powell - Whitten 1993; Anderson 2000a; Bengtsson 2004; Duch - Stevenson 2008; Bellucci Lewis-Beck 2011; Fraile - Lewis-Beck 2014). Consequently, it is interesting to understand the role of systemic features for accountability in Central and Eastern Europe.

Economic voting showed to be unstable, varying across countries, so that a large amount of literature (e.g. Powell - Whitten 1993; Bengtsson 2004; Nadeau - Niemi - Yoshinaka 2002; Bellucci - Lewis-Beck 2011; Hobolt - Tilley Banducci 2012) have tried to explain it as a problem concerning the selection of cases and measurement techniques. This instability would be induced by "faulty measurement of the economic and political components," together with the problems of "small, country-specific samples" (Bellucci - Lewis-Beck 2011: 205). Studies on electoral accountability in CEE countries have usually lacked in presenting wide cross-national analysis involving the use of "targeted" variables (at the individual or aggregate level), able to capture performance evaluation or those specific characteristics of the political context that shape electoral accountability.

1 On the other side, O'Donnell (1998: 112-113) states the "limited" role exerted by "free and fair recurrent elections" for vertical accountability. In fact, underlining the importance of freedom of speech, press and association to pursue both answerability and enforcement he affirms that "elections occur only periodically, and their effectiveness at securing vertical accountability is unclear, especially given the inchoate party systems, high voter and party volatility, poorly defined issues, and sudden policy reversals that prevail in most new polyarchies." 
Given the peculiar level of political sophistication and participation in the region $^{2}$ (Zaller, 1990; Howard 2002), it is necessary to employ economic and political variables able to capture the characteristics of the voters. In fact, in many fluid party systems-such as those characterizing CEE democracies-characterized by weak ideological ties and voters' evaluations of leaders are not based on programmatic or ideological principals (Katz - Crotty 2006). For this reason, voters are more likely to vote according to retrospective evaluations of incumbent performance. We do not limit our analysis to test the influence of formal institutional rules on performance voting, but we enrich the study by looking at how specific characteristics of the incumbent government and the degree of freedom of the mass media influence electoral accountability in CEE countries.

Figure 1 Level of electoral turnout among the 28 EU Member States

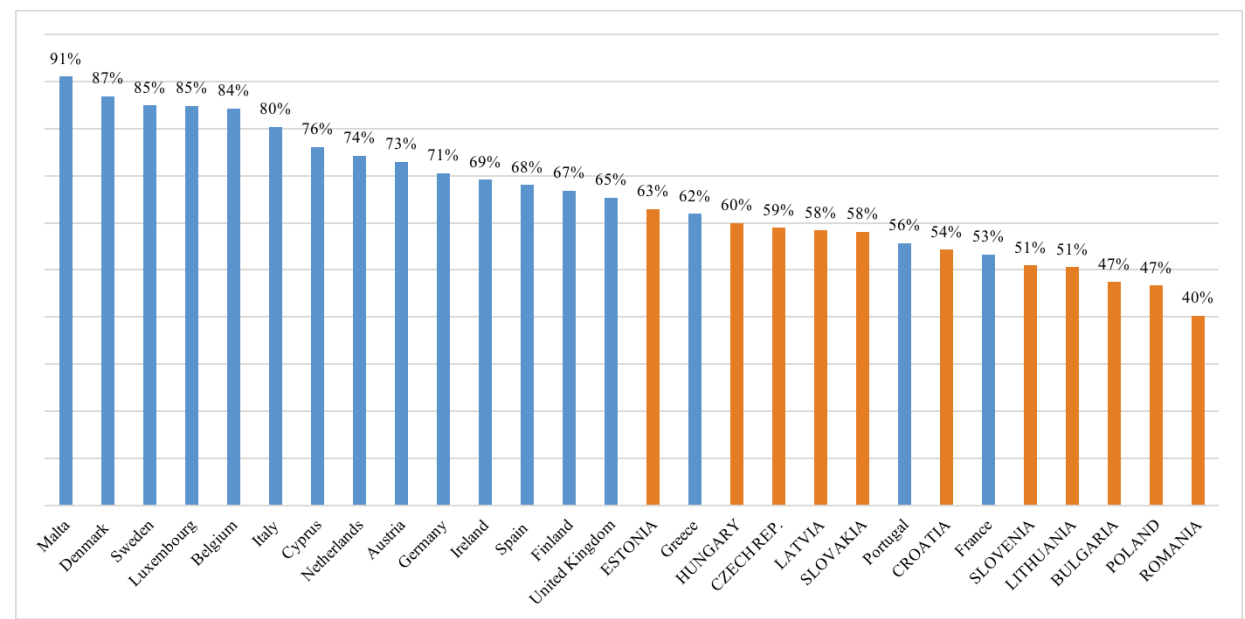

Note: Turnout in the last national legislative election held before the 2014 European elections

First, we briefly review the literature on electoral accountability, mostly in the framework of economic voting and clarity of responsibility. Then, we present our theoretical propositions concerning the effects of specific aspects of the institutional context and the degree of freedom of the mass media. We test these propositions using a multilevel analysis of survey data from eleven European countries. The results show that voters' ability to hold governments to account is greatly influenced by the contingent characteristics of the political context.

2 According to Luskin (1990) we consider political sophistication as the "ability-motivation-opportunity triad" influencing voters when they cast their vote. In the literature ability has been usually operationalized as level of education, motivation has been measured using indicators of political interest, while opportunity-considered as the availability of information in a given political context-refers to more contextual factors (Luskin 1990; Popa 2013). 
Our results also demonstrate the moderating impact of the mass media on performance voting, indicating the opportunity to include them in the study of electoral accountability. The conclusion looks at the implications of these findings.

\section{Electoral accountability: previous approaches}

The literature on electoral accountability developed around the theories of economic voting, that is how voters punish or reward incumbent governments according to the state of the national economy. The number of works in this field is now "around 400 by one count" (Lewis-Beck - Stegmaier 2007: 520). According to this approach, voters tend to reward the incumbent when the economy has improved and are inclined to punish him when economic conditions have gotten worse (Lewis-Beck - Stegmaier 2000; De Brug - Van der Eijk - Franklin 2007; Duch - Stevenson 2008; Dassonneville - Lewis-Beck 2014). In this perspective, an incumbent government would be judged retrospectively, i.e. looking at its economic policy outcomes, often measured using macroeconomic indicators such as inflation, unemployment, growth, or value of national currency (Dorussen - Taylor 2002).

In this perspective, re-election to the office in a given period $t$ would be based on economic performance in period $t-1$. According to Fiorina (1981: 430) such a model "presumes that citizens look at results," 3 i.e. they only consider whether the national economic condition improved or not when they cast their vote.

However, studies conducted over the last twenty years in Central and Eastern Europe present variegated evidence. Several studies using public opinion data found that economic performance affected evaluations of incumbents: Przeworski (1996) showed a co-variation between government popularity and the unemployment rate in Poland; Duch (1995) found that economic difficulties undermine support for governments in the USSR, Hungary, Poland, and the Czech Republic; Duch (2001) and Anderson as well as Lewis-Beck and Stegmaier (2003) found evidence of economic voting in Hungary. Using sub-national data from early in the transition, Stegmaier and Lewis-Beck (2009) found that the Hungarian electorate acts as economic voters, following an incumbency-oriented strategy.

Other studies-often using sub-national data-found that the relation between economic conditions and voting behavior seems to be mediated by per-

3 Another question characterizing economic voting literature is what economic conditions voters look at when they decide in the polls. According to a common belief, voters vote according to their pocketbook, i.e. when personal or household financial conditions deteriorate, voters punish the incumbent. Otherwise, they will reward the incumbent. Nevertheless, the overwhelming majority of studies have found that instead of emphasizing personal economic condition, voters are much more likely to be considering the national economic situation when casting their vote (Lewis Beck - Stegmaier 2000; Nadeau - Lewis-Beck - Bélanger 2012). 
ceptions of party type more than government performance. According to Pop-Eleches and Tucker (2011), voters look mainly at whether a party is connected with the new or old regime rather than its responsibility for current economic performance. Powers and Cox (1997), using cross-sectional data from the 1993 Polish election, similarly found that attitudes toward economic reforms have a limited effect on voting behavior, but their importance is eclipsed by understandings of the past and other factors, such as religion. In an unrelated study, Harper (2000) found only weak effects of economic evaluations on vote choices in three countries. Given the variety of results, it is not certain whether economic voting would also be obtained at a cross-national level.

Scholars have gradually come to the point that the economic effect as such is not sufficient to explain voters' assignment of responsibility, but it is stronger in relation to other factors related to the political context (e.g. Powell - Whitten 1993; Whitten - Palmer 1999; Bengtsson 2004; Anderson 2007; Hellwig Samuels 2008; Hobolt - Tilley - Banducci 2013). The awareness that explaining electoral accountability means analyzing those aspects related to Schedler's definition (i.e. answerability and enforcement) gradually spread among political scientists. An extensive amount of literature has begun to look at the influence of political context on voters' assignment of responsibility to the government for economic performance.

Powell and Whitten (1993) showed that economic voting is conditioned by the "clarity of responsibility" of political institutions. Institutional arrangement matters for voters' possibility to punish or reward governments for economic performance: "The greater the perceived unified control of policymaking by the incumbent, the more likely the citizen is to assign responsibility for economic and policy outcomes to the incumbents" (Powell - Whitten 1993: 398). Even if it is of indisputable importance, this study, and the several works which followed its approach, present the limit for analyzing almost exclusively stable, industrialized democracies, or adapting the same variables in the analysis of new democracies. It is thus not clear to what extent economic voting would occur in new democracies without traditions of holding governments accountable, such as the CEE countries. These studies, while also giving important theoretical and methodological contributions, leave open some questions, in particular regarding the contexts to look at in the analysis of accountability in new democracies.

The relevance of the context, conceived as the political environment able to mediate the effects of individual-level factors on citizens' behavior (Anderson 2007), suggests looking at several of its components, such as government clarity of responsibility (Bengtsson 2004; Hobolt et al. 2013), the existence of available alternatives (Anderson 2000) to the government, the influence of the electoral system (Powell 2000) and-as Schedler's conception of accountability suggests-the possibility for citizens to be informed through a free and 
pluralistic mass media. These four components, in fact, may contribute to the functioning mechanism of accountability, ensuring information about the political acts promoted by the incumbent and the possibility for voters to identify and potentially to sanction it.

But relevance lies not only in the government and party system. Evidence from the literature supports the idea that media action promotes accountability. Reports from the media about a government's action lead to better informed voters and, as a consequence, this increases politicians' accountability (Besley - Burgess 2002; Ashworth 2012). Norris (2013) suggests that the principal function of the media is to serve as "watchdogs" defending the public interest, functioning as agenda-setters to focus citizens' attention on pervasive problems, such as the economic performance of a national government. Looking at the definition of accountability proposed by Schedler (1999), in fact, the media can (indirectly) influence answerability and enforcement, empowering citizens to play an effective role in holding government to account. The mass media may function as a stimulus for individuals, pushing them to demand information about actions undertaken by elected officials and enforce sanctions, by creating opportunities to do this.

In the last decade, more and more studies have tried to adopt both new economic and systemic variables in order to capture the strength and intensity of the relationship with the dependent variable (Bengtsson 2004; Coffey 2013; Foucault - Seki - Whitten 2013; Hobolt - Tilley - Banducci 2013). However, as stressed by Bellucci and Lewis-Beck (2011) this literature seems to lack to design a set of variables able to fit specific cases.

For these reasons, the present literature review encourages the carrying out of cross-national research on electoral accountability in eleven CEE countries which now belong to the European Union but were part of the "Communist Bloc" until 1989. To do this, we have employed specific variables, capable of capturing the peculiar aspects of our sample countries.

\section{Does political contest really matter? Government, parties, and the mass media}

Voters' behavior is influenced by the contexts in which they operate (Powell 2000). Assuming the relevance of these components for the study of electoral accountability, the aim of this research will also be to extend the clarity of responsibility approach, as developed by the literature, finding what contexts are of importance. The main aim of the article is to show how political context influences the accountability mechanism in Central and Eastern European democracies.

However, before doing this, it is interesting to understand the extent to which CEE citizens' voting behavior is driven or not by the economic performance 
of the country. Hence, our first hypothesis assumes that the incumbent vote share is positively influenced by variation in the GDP growth rate and negatively influenced by variations in unemployment and inflation $\left(\mathrm{H}_{1}\right)$. The starting point, in fact, is to question the validity of the economic voting theory applied to Central and Eastern Europe since most of the possibilities for voters to punish/ reward the incumbent derives from the perception they have regarding his/her performance (Key 1966; Lewis-Beck - Stegmaier 2000). Using evidence derived from previous research (Roberts 2010; Coffey 2013), the first hypothesis tests the effect of three macroeconomic variables-GDP growth, unemployment, and inflation-on electoral support for the incumbent government. This choice is not only dictated by the historical experience of these countries, but also by the evidences coming from previous research that has also demonstrated that the strength of the link economy/vote choice varies considerably across countries (Paldam 1991; Anderson 2000b; Anderson 2007; Bellucci - Lewis-Beck 2011).

Following an approach developed in the literature on consolidated democracies to explain Paldam's contingency dilemma, the further aim of this article is to go beyond economic voting theory, analyzing the importance of the political contexts-first of all of the institutional components-for electoral accountability in CEE. Anderson (2007: 590) stresses the importance of the political contexts for voters' behavior:

"In a very basic way, then, context and behavior are intimately connected, and this connection is at the heart of political life in at least two fundamental ways: first, formal and informal rules affect people's political behavior, and people's preferences, attitudes, and behavior affect the establishment and functioning of such rules. Second, citizens are exposed to variable social, political, and economic environments that they are called upon to understand and interpret and that they may seek to shape based on these understandings and interpretations."

In order to look comprehensively at Anderson's political contexts, this study moves then to consider three specific aspects of the institutional system: government clarity of responsibility, structure of the party system, and characteristics of the voting system. All of them are considered not only for their direct effect on the dependent variable, but especially for their conditional effect to be able to strengthen or weaken the accountability mechanism.

Regarding government clarity of responsibility, we hypothesize electoral accountability to be weaker in a situation characterized by highly unstable, divided, and minority governments $\left(\mathrm{H}_{2}\right)$. A fair amount of literature on this topic (Powell and Whitten 1993; Anderson 2000; Hobolt - Tilley - Banducci 2013) shows how voters' ability to punish/reward the incumbent is highly influenced by the extent to which it is clear who is responsible for what, i.e. government responsibility for economic performance is evident. This is undoubtedly clearer in cases of stable, majority, and small-size coalition governments. 
Turning to the structure of the party system-i.e. the degree of fragmentation-and its conditional effect, we can hypothesize that performance voting is stronger in contexts characterized by a small number of effective parties $\left(\mathrm{H}_{3}\right)$. The literature on this point has shown that in order to facilitate the accountability mechanism it is important for voters to have clear and credible alternatives (Anderson 2000; Bengtsson 2004). When the opposition is extremely fragmented, voters are likely to refuse to vote for these parties, considering them not able to form a government after the elections. They will refuse to cast their vote against the incumbent and so breaking, to some extent, the link performance-accountability.

Considering the characteristics of the electoral system, we can hypothesize that elections held using proportional systems tend to favor the fortunes of the incumbent government $\left(\mathrm{H}_{4}\right)$. Several studies show how majoritarian systems provide for a more accountable system for two reasons-one more practical and the other more theoretical. On one hand, majoritarian systems often imply that an incumbent vote loss corresponds to a decisive turnover replacement, while under proportional formulas the government's punishment tends to be less direct. In addition, because of the single-member constituency system, voters hold more power to directly reward or punish incumbents at the elections. On the other hand, proportional systems are often based on party-list, blocked list, or wide-nation list that could impede the direct voters' assignment of responsibility at the polls (Powell 2000; Hobolt - Klemmensen 2008; Van der Eijk - Franklin 2009).

However, even in an archetypical "high clarity" system, in fact, the relationship between an incumbent's performance and his survival in office is relatively weak precisely because the incumbent government benefits from the electoral system's distortion of a plurality of votes into a majority of seats (Hellwig Samuels 2008). Clarity of responsibility alone, in fact, could not completely explain the relationship between incumbent performance and incumbent re-election. The main aim of this work, in other words, is to understand what contextual variables deeply affect voters' possibility of sanctioning/rewarding incumbents in the new European democracies. This consideration leads to the last hypothesis.

Our fifth hypothesis, in fact, concerns the moderating effect of the media on electoral accountability. In this case we expect a pluralistic and free mass media to have a positive conditional effect, making voters more aware of the economic performance of the incumbent government $\left(\mathrm{H}_{5}\right)$. A great deal of literature is devoted to the relationship between the media and politics. A part of it analyses the effects of the media on electoral participation (Smets - Van Ham 2013), while other studies focus on its role in the development of political knowledge (Fishkin 1991; De Vreese - Boomgaarden 2006). Studies have also demonstrated that political debates contribute to long-term political engage- 
ment and voters' issue knowledge and salience. However, a number of studies on electoral accountability do not include the media as an independent variable. That is, while many of them do analyze the influence of media coverage of the economy on individuals' economic evaluations and perceptions (Mutz 1994; Haller - Norpoth 1997; Soroka 2006), substantially fewer studies analyze the impact of the media on individuals' vote choices. Nevertheless, the media play a relevant role in ensuring accountability, since they work as a harness on government action and political institutions in general (Birch 2011; Birch Van Ham 2014). Their "watchdog" action, in other words, allows citizens to be informed about problems, making them aware of incumbent's performance (Norris 2015). Government accountability to the citizens turns out strengthened where independent media make the public aware about, for instance, the national economic situation. An independent and pluralistic media system has been proven to have positive effects on the quality of elections as well for two reasons. First of all, by providing an unbiased source of news, especially about the performance of the incumbent government in terms of public and economic policies. For this reason, we very frequently assist the media in emphasizing mostly negative information about the governing parties (Sokora 2006), strengthening the link between performance and vote choices at the basis of the accountability mechanism.

This article tests these hypotheses by looking at eleven new democracies in Central and Eastern Europe. The decision to focus on these countries lies in their peculiarities. The existence of relatively new party systems, usually characterized by high fragmentation, implies that citizens could have difficulty finding targets for accountability (Bunce - Csanadi 1993; Birch 2003; Rose - Munro 2011). Moreover, recent data as well as the literature have shown that citizens in post-communist countries are far less likely to participate in politics than those belonging to Western Europe or other new democracies (see Howard 2002; Eurostat 2013). Less interested and politically active citizens will tend to acquire less information about governance outcome. As a result, they may not possess the necessary information to practice performance voting since more informed voters are better able to use elections to screen and discipline elected officials (Besley 2006; Glaeser - Ponzeto - Shleifer 2007).

\section{Data and methods}

In order to test our theoretical propositions, we use individual level data from the 2014 European Election Study (EES), which is a cross-national survey that covers all EU-28 countries and, among them, our eleven CEE countries. Since the present research analyzes only eleven Member States, the total sample is composed of roughly 12,000 respondents. Since the questionnaire is administered in the 28 countries during the same period, the EES represents an 
interesting instrument to examine how cross-national variation in the political context shapes individual-level voting behavior at the same time (Hobolt Tilley - Banducci 2013).

Table 1: Descriptive statistics

\begin{tabular}{|c|c|c|c|c|c|c|}
\hline Variable & $\mathbf{N}$ & Code & Mean & SD & Min & Max \\
\hline Incumbent vote & 8,647 & $0-1$ & 0.32 & 0.46 & 0 & 1 \\
\hline GDP growth & 8,647 & - & 2.44 & 1.11 & -0.36 & 3.67 \\
\hline Unemployment & 8,647 & - & 10.3 & 3.7 & 6.20 & 16.70 \\
\hline Inflation & 8,647 & - & 0.03 & 0.61 & -1.42 & 1.7 \\
\hline Clarity index & 8,647 & $0-3$ & 1.45 & 0.93 & 0 & 3 \\
\hline ENEP & 8,647 & - & 4.96 & 1.60 & 2.54 & 7.59 \\
\hline Electoral system & 8,647 & $0-1$ & 0.18 & 0.40 & 0 & 1 \\
\hline FoP index & 8,647 & $0-100$ & 70.72 & 8.56 & 58 & 84 \\
\hline
\end{tabular}

Our dependent variable is an individual-level measure for national vote intention. It is measured using the traditional question in the EES questionnaire: "....and if there was a general election tomorrow, which party would you vote for?". Answers to this question are dichotomized, building up a binary dependent variable that runs from 0 (vote for opposition parties) to 1 (vote for incumbent government/party). ${ }^{4}$ It allows us to use multilevel logistic regression models to analyze the relation between the dependent and the independent variables.

To test the direct accountability effect we use three key independent variables. We adopt macroeconomic indicators for inflation, unemployment and annual GDP growth (International Monetary Fund, 2014). Inflation is measured as the change in percentage of average consumer prices year by year. Unemployment is measured as the percentage of people who are currently not working but are currently searching for work. GDP growth is measured as the annual change in percentage of gross domestic product.

In order to analyze the conditional effect of Anderson's political "contexts," indicators for government clarity of responsibility, party system structure, type of electoral system and freedom of the media are used in the analysis. As measure of government clarity, we adopt an additive index that collects specific characteristics of government status: minority/majority government (0-1), coalition/one-party government (0-1) and stability (0-1). For each country

4 We thus exclude non-voters from the analysis. We also dropped "Don't know," "No answer," and refusals from the dataset. In this way, we obtained roughly 8,000 responses. 
the scores are added creating an index running from zero to three. To measure the structure of the party system we use the effective number of parties at the election (Gallagher 2015). A categorical variable is employed to classify the different electoral systems (Bormann - Golder 2013). We distinguish between mixed and proportional system, taking the first one as the reference category. ${ }^{5}$ Media freedom is measured using the Freedom of the Press Index published in 2014 by Freedom House (2015). We reversed the original index, so that each country is given a total press freedom score from 100 (best) to 0 (worst) on the basis of 23 methodology questions divided into three subcategories. ${ }^{6}$

\section{Findings}

Given the different nature of the data-collected at both the macro and micro level-data are analyzed using logistic multilevel models (Steenbergen - Jones 2002). Table 1 presents fou*r models with a logit link because the binary nature of the dependent variable (0-1). The first model tests the traditional propositions of economic voting, i.e. the propensity for voters to vote for the incumbent government according to its economic performance $\left(H_{1}\right)$. The aim of Models 2-3-4 is to test the main and conditional effect of our institutional variables on electoral accountability, introducing the clarity of responsibility index, the availability of governing alternatives, and the electoral system $\left(\mathrm{H}_{2}\right.$, $H_{3}$ and $H_{4}$ ). The fifth model tests the moderating effect degree of media freedom on voters' ability to assign responsibility for economic performance, so explicitly testing $H_{5}$.

Table 2: Multilevel logit regression models of incumbent vote intention in Central and Eastern Europe

\begin{tabular}{|l|l|l|l|l|l|}
\hline & Model 1 & Model 2 & Model 3 & Model 4 & Model 5 \\
\hline Unemployment & $-0.11^{* *}(0.02)$ & $-0.23^{* *}(0.02)$ & $-0.16^{* *}(0.08)$ & $-0.11^{* *}(0.02)$ & $-0.15^{* *}(0.02)$ \\
\hline GDP growth & $0.05(0.08)$ & $0.04(0.05)$ & $0.03(0.07)$ & $0.01(0.09)$ & $0.01(0.08)$ \\
\hline Inflation & $-0.07 * *(0.01)$ & $-0.11^{*}(0.04)$ & $-0.09 *(0.07)$ & $-0.12 *(0.02)$ & $-0.10(0.03)$ \\
\hline & & & & & \\
\hline Clarity of responsibility index & & $-0.63 * *(0.21)$ & & & \\
\hline Clarity * GDP & & $0.32 *(0.29)$ & & & \\
\hline Clarity * Unemployment & & $0.49 * *(0.15)$ & & & \\
\hline Clarity * Inflation & & $0.43(0.12)$ & & & \\
\hline
\end{tabular}

5 We do not consider majoritarian systems that failed to be adopted by the sample countries. Among them, only Hungary, Lithuania and Romania use a mixed voting system. Data are available at http:// www.ipu.org/parline-e/parlinesearch.asp.

6 For details see the complete report available at: https://freedomhouse.org/sites/default/files/FreedomofthePress_2015_FINAL.pdf 


\begin{tabular}{|c|c|c|c|c|c|}
\hline & Model 1 & Model 2 & Model 3 & Model 4 & Model 5 \\
\hline Party system fractionalization & & & $0.49 *(0.22)$ & & \\
\hline Party system frag. * GDP & & & $-0.41(0.18)$ & & \\
\hline $\begin{array}{l}\text { Party system frag. * Unem- } \\
\text { ployment }\end{array}$ & & & $-0.36 *(0.19)$ & & \\
\hline Party system frag. * Inflation & & & $-0.33(0.23)$ & & \\
\hline Electoral system & & & & $-0.23(0.46)$ & \\
\hline Electoral system * GDP & & & & $0.29(0.33)$ & \\
\hline $\begin{array}{l}\text { Electoral system * Unemploy- } \\
\text { ment }\end{array}$ & & & & $0.18(0.25)$ & \\
\hline Electoral system * Inflation & & & & $0.21(0.37)$ & \\
\hline Freedom of the Press index & & & & & $-0.83 *(0.27)$ \\
\hline FoP index * GDP & & & & & $0.39(0.19)$ \\
\hline FoP index * Unemployment & & & & & $0.50 * *(0.10)$ \\
\hline FoP index * Inflation & & & & & $0.13 *(0.05)$ \\
\hline Constant & $0.46 * *(0.15)$ & $0.74(0.26)$ & $0.46 *(0.27)$ & $0.65(0.33)$ & $0.82 *(0.23)$ \\
\hline $\mathrm{N}$ : countries & 11 & 11 & 11 & 11 & 11 \\
\hline $\mathrm{N}$ : individuals & 8,647 & 8,647 & 8,647 & 8,647 & 8,647 \\
\hline Log likelihood & $-4,358.16$ & $-4,533.43$ & $-4,635.56$ & $-4,646.65$ & $-4,761.78$ \\
\hline Nagelkerke Pseudo R² & 0.52 & 0.49 & 0.43 & 0.47 & 0.51 \\
\hline
\end{tabular}

Notes: Dependent variable: support to incumbent government. Standard errors in parentheses. Coefficients: $* \mathrm{p}<0.1 ; * \mathrm{p}<0.05 ; * * * \mathrm{p}<0.01$

Model 1 simply collects the results of a multiple regression of national vote intention on our three macroeconomic variables. It indicates that two out of three economic indicators, i.e. unemployment and inflation, are very statistically significant (at 95 percent), also the coefficients point in the correct direction: higher unemployment and inflation make people less likely to be incumbent government voters. These findings seem to support our first hypothesis. Voters in our CEE countries look "retrospectively" at the incumbent's economic performance when they cast their vote and are particularly sensitive to specific economic indicators, such as unemployment and inflation. The almost absence of unemployment during the Communist regime, together with skyrocketing inflation rates ${ }^{7}$ after its fall in the 1990s (for instance, in Poland it reached 525

7 For an overview, see World Bank data available at: http://data.worldbank.org/indicator/NY.GDP.DEFL. KD.ZG?page $=5$. 
percent), has probably made citizens in these countries more sensitive to some aspects of the economy rather than others, such as GDP growth (Przeworski 1996; Roberts 2012; Coffey 2013).

Model 2 tests the main and conditional effect of our first systemic variable, i.e. government clarity, on the accountability process. Results seem to confirm our theoretical statements: lower levels of government cohesion and government stability seem affect the propensity to vote for the incumbent. Moreover, in this case interaction coefficients are consistent and statistically significant, in particular for unemployment and, surprisingly, for GDP growth as well. Hence, our hypothesis is partially confirmed: in contexts in which "lines of responsibility" are clearer voters" ability to sanction/reward incumbents according to their performance is enhanced, with particular regard to unemployment policies and GDP growth. In Model 3 the results show that in countries with less fragmented party systems, economic effects increase more than countries in which ENEP is higher. Interaction terms, in fact, suggest that in contexts in which there are fewer and sizeable alternatives to the incumbent government, voters tend more to sanction it for bad performance, this time in the area of unemployment. These results lead to a partial acceptance of our third hypothesis. Model 4 tests how the electoral system influences link performance-accountability. However, the existing-negative-relationship with our dependent variable finds support in recent literature on voting behavior in Western Europe. The main effect indicates that non-proportional voting systems tend to affect negatively electoral support for the government. Moreover, the positive coefficient of the interaction terms suggests that mixed systems tend to favor accountability dynamics much more than PR systems. However, none of these values show statistically significant effects, so we should reject our fourth hypothesis. In Model 5 our fifth hypothesis is tested. In this case, the model gives strongly statistically significant results, with both the main effect and the interaction terms pointing in the expected direction. In this case the media seem to play an undeniable role in favoring electoral accountability in our eleven CEE countries. It means that in countries where citizens can count on a fairer media-in terms of both political pluralism and concentration of economic resources-are less likely to vote for the incumbent government. Moreover, the highly significant interaction between this variable and our macroeconomic indicators-in particular unemployment-confirms that more freedom of the media makes citizens better informed to carry out retrospective voting.

\section{Conclusion}

The aim of this article is multiple. It aims to contribute to the existing literature on electoral accountability. For long time, it has focused almost exclusively on economic voting, studying the relationship between electoral outcomes 
and the state-or the perception-of the economy. In the last decade, a large body of literature moved its focus to the influence of the institutional system on electoral accountability. This cross-national study aims to contribute to this literature, focusing on eleven countries belonging to Central and Eastern Europe but also addressing economic voting theory and adapting clarity of responsibility assumptions to these specific cases. Moreover, it aims to be a first attempt to also include the mass media in a cross-national analysis of electoral accountability. The results seem to corroborate the general findings. Contexts with higher institutional clarity have more pronounced levels of performance voting than countries with more government instability and fragmentation of the party system. Moreover, it seems confirmed that greater media pluralism improves the accountability mechanism, furnishing citizens with useful information about the state of the economy that can be used when they cast their votes at the polls.

We started from the general assumption that citizens' ability to perform retrospective voting is enhanced when electoral accountability is simple. In post-communist EU Member States real economy-and unemployment above all-matters, but it is not enough. Our results show that as for consolidated democracies, in Central and Eastern Europe voters' economic assessments have stronger effects on government support when it is clear who is responsible for whom, when voters have only a limited number of (credible) alternatives to throw their support to and when there is a free media system able to surveil government and identify problems. Hence, this study demonstrates the relevance-also for these new democracies-of the "political contexts" represented by the government, parties, voting systems and mass media, and in which areas economic voting takes place. Who is in charge? How much responsibility does that person have? What are the alternatives to the present government? These, as well as the watchdog function of the mass media, represent key elements that seems to dramatically influence whether and to what extent voters hold governments to account for their actions.

The results suggest that clarity matters, and it is twofold-on the side of government/incumbent and on the side of opposition/possible incumbent. Voters blame/credit the national government, but if it is not strong, cohesive, and able to make decision they will find it difficult to effectively sanction the incumbent. Moreover, too fragmented alternatives are associated with higher levels of support for an incumbent government: it will be more difficult for voters to estimate what an alternative government would look like, since more parties compete for power. In other words, in order to work, the circuit of electoral accountability needs clarity on different levels of the political system: government, opposition/political parties, and finally the media. Regarding the media, this article underscores their importance in strengthening accountability in CEE countries. As already found in previous research (Sheafer 2008; Aker - Collier - Vicente 
2010), citizens pick up cues regarding the situation of the economy from the media, and this eventually affects their voting behavior. The findings of this article go in this direction, in particular looking at the interactions between the media and the economy in influencing voters' decisions. Of course, this is one of the first attempts to study the influence of the media on the electoral accountability process, and there is still such a long way to go, in particular in the selection of fitting indicators.

Nevertheless, new problems emerge with the presence of European Union-in particular for the countries belonging to the Eurozone-because its presence risks blurring the lines of responsibility and making it more difficult for voters to assign responsibility and sanction governments on the basis of their performance. Zielonka (2007) stresses that the limits of the EU structure of democratic decision making are much more multilayered and multicentered than at the national level. Evidence from Latin America tells us that citizens often blame policy outcomes on international actors, to which they, as voters, have no direct influence (Alcaniz - Hellwig 2010). A further step in the study of electoral accountability in CEE countries could be to test voters' attitudes. Do they continue to consider national governments responsible for national economic performance, or do they blame the European Union for the recent-and potential future-economic troubles? In any case new theoretical and methodological problems and for researchers and policymakers inevitably seem to rise.

\section{References}

Alcaniz, Isabella and Hellwig, Timothy (2010): Who's to Blame? The Distribution of Responsibility in Developing Democracies. British Journal of Political Science 41 (2): 389-411.

Anderson, Christopher J. (2000a): Economic Voting and Political Context: a Comparative Perspective. Electoral Studies 19: 151-170.

Anderson, Christopher J. (2000b): The End of Economic Voting? Contingency Dilemmas and the Limits of Democratic Accountability. Annual Review of Political Science 10: 271-296.

Anderson, Christopher J. (2007): The Interaction of Structures and Voter Behavior, in Dalton, Russel J. and Klingemann Hans-Dieter, eds., The Oxford Handbook of Political Behavior. Oxford University Press.

Anderson, Leslie - Lewis-Beck, Michael S., and Stegmaier, Mary (2003): Post-Socialist democratization: a comparative political economy model of the vote for Hungary and Nicaragua. Electoral Studies 22: 469-484.

BBC (2012): Conceptualizing Accountability. An Approach to Measurement: BBC Media Action: Bridging Theory and Practice Research Dissemination Series, Working Paper No. 2012/2. 
Bellucci, Paolo and Lewis-Beck, Michael S. (2011): A Stable Popularity Function? Cross-national Analysis. European Journal of Political Research 50: 190-211.

Bengtsson, Asa (2004): Economic Voting: The Effect of Political Context, Volatility and Turnout on Voters' Assignment of Responsibility. European Journal of Political Research 43: 749-767.

Besley, T. and Burgess, R. (2002): The Political Economy of Government Responsiveness: Theory and Evidence from India. Quarterly Journal of Economics 117 (4): 1415-1451.

Besley, T. (2006). Principled Agents? The Political Economy of Good Government. The Lindahl Lectures, Oxford University Press

Birch, Sara (2003): Electoral Systems and Political Transformation in Post-Communist Europe. Palgrave Macmillan.

Birch, Sara and Van Ham, Carolien (2014): Getting away with foul play? How oversight institutions strengthen election integrity. Paper presented at the Annual Conference of the Midwest Political Science Association, Chicago, 3-6 April 2014.

Bormann, Nils-Christian and Golder, Matt (2013): Democratic Electoral Systems around the world, 1946-2011. Electoral Studies 32 (2): 360-369.

Bunce, Valerie and Csanadi, Maria (1993): Uncertainty in transition: post communism in Hungary. East European Politics and Societies 7: 240-275.

Coffey, Eva (2013): Pain Tolerance: Economic Voting in the Czech Republic. Electoral Studies 32: 432-437.

Dahl, Robert (1971): Poliarchy: Participation and Opposition. New Haven: Yale University Press.

Dassonneville, Ruth and Lewis-Beck, Michael S. (2014): Macroeconomics, economic crisis and electoral outcomes: A national European pool. Acta Politica 49: 372-394.

De Broug, Wouter - Van der Eijk, Cees, and Franklin, Mark (2007): The Economy and the Vote: Electoral Responses to Economic Conditions in 15 Countries. Cambridge University Press.

Duch, Raymond M. (1995): Economic chaos and the fragility of democratic transition in former communist regimes. Journal of Politics 57: 121-158.

Duch, Raymond M. (2001): A developmental model of heterogeneous economic voting in new democracies. American Political Science Review 95: 895-910.

Duch, Raymond M. and Stevenson, Randolph T. (2008): The Economic Vote: How Political and Economic Institutions Condition Election Results. Cambridge University Press.

Eurostat (2013): Quality of Life Indicators-Governance and Basic Rights. Available at: http:// ec.europa.eu/eurostat/statistics-explained/index.php/Quality_of_life_indicators_-_governance_and_basic_rights.

Fiorina, Morris (1981): Retrospective Voting in American National Elections. Yale University Press.

Foucault, Martial - Seki, Katsunori, and Whitten, Guy D. (2013): Electoral Accountability in European Hard Times. Paper presented at the 2013 EUDO Dissemination Conference. Florence, Italy.

Freedom House (2015), Freedom of the Press 2015: available at

https://freedomhouse.org/sites/default/files/FOTP\%202015\%20Full\%20Report.pdf

Gallagher, Michael (2015) Election indices dataset: available at 
http://www.tcd.ie/Political_Science/staff/michael_gallagher/ElSystems/index.php.

Glaeser, E., G. Ponzeto, and A. Shleifer (2007). Why does democracy need education?. Journal of Economic Growth 12 (77): 59-73.

Harper, Marcus A. G. (2000): Economic voting in post-communist Eastern Europe. Comparative Political Studies 33: 1191-1227.

Hellwig, Timothy and Samuels, David (2007): Electoral accountability and the variety of democratic regimes. British Journal of Political Science 37: 1-26.

Howard, Marc M. (2002): The Weakness of Civil Society in Post-Communist Europe. Cambridge University Press.

Lewis-Beck, Michael S. (1988): Economics and Elections: The Major Western Democracies. University of Michigan Press.

Lewis-Beck, Michael S. (1991): Introduction, in Norpoth, Helmut - Lewis-Beck, Michael S., and Lafay, Jean Dominique, eds., Economics and politics: The calculus of support. University of Michigan Press.

Lewis-Beck, Michael S. and Stegmaier, Mary (2000): Economic determinants of electoral outcomes. Annual Review of Political Science 3: 183-219.

Lewis-Beck, M.S. \& Stegmaier, M. (2007). Economic models of the vote. In R. J. Dalton \& H.-D. Klingemann (eds), The Oxford Handbook of Political Behaviour. Oxford: Oxford University Press.

Lewis-Beck, Michael S. and Stegmaier, Mary (2007): Economic models of the vote, in Dalton, Russel J. and Klingemann Hans D., eds, The Oxford Handbook of Political Behaviour. Oxford University Press.

Lijphart, Arend (1999): Patterns of Democracy: Government Forms and Performance in Thirty-Six Countries. Yale University Press.

Maloy, Jason S. (2014): Linkages of Electoral Accountability: Empirical Results and Methodological Lessons. Politics and Governance 2(2): 13-27.

Morlino, Leonardo (2004): What is a Good Democracy?. Democratization 11: 10-32.

Morlino, Leonardo (2011): Changes for Democracy: Anchors, Structures and Processes. Oxford University Press.

Nadeau, Richard - Lewis-Beck, Michael S., and Bélanger, Eric (2012): Economics and Elections Revisited. Comparative Political Studies 20(10): 1-23.

Paldam, Martin (1991): How robust is the vote function? A study of seventeen nations over four decades, in Norpoth, Helmut - Lewis-Beck, Michael S. and Lafay, Jean Dominique, eds., Economics and Politics: The Calculus of Support. University of Michigan Press.

Powell, Bingham G. and Whitten, Guy D. (1993): A cross-national analysis of economic voting: taking account of the political context. American Journal of Political Science 37: 391-414.

Powell, Bingham G. (2000): Elections as Instruments of Democracy. Majoritarian and Proportional Visions. Yale University Press.

Powell, Bingham G. (2004): The Chain of Responsiveness. Journal of Democracy 15(4): 91-105. 
Powers, Denise V. and Cox, James H. (1997): Echoes from the past: the relationship between satisfaction with economic reforms and voting behavior in Poland. American Political Science Review 91: 617-633.

Przeworski, Adam (1991): Democracy and the Market. Cambridge University Press.

Przeworski, Adam (1996): Public support for economic reforms in Poland. Comparative Political Studies 29: 520-543.

Przeworski, Adam and Cheibub, José A. (1999): Democracy, elections, and accountability for economic outcomes, in Przeworski, Adam - Stokes, Susan, and Manin, Bernard, eds., Democracy, Accountability, and Representation. Cambridge University Press.

Roberts, Andrew (2012): The Quality of Democracy in Eastern Europe. Cambridge University Press. Rose, Richard - Munro, Neil (2003): Elections and Parties in New European Democracies. CQ Press.

Schedler, Andreas (1999): Conceptualizing Accountability, in Schedler, Andreas - Diamond, Larry - Plattner, and Marc F., eds., The Self-Restraining State: Power and Accountability in New Democracies. Routledge.

Sheafer, Tamir (2008): The Media and Economic Voting in Israel. International Journal of Public Opinion Research 20 (1): 33-51.

Smets, Kaat and Van Ham, Carolien (2013): The embarrassment of riches? A meta-analysis of individual level research on voter turnout. Electoral Studies 32: 344-359.

Stegmaier, Mary (2009): Elections, Parties and Voters in the New European Democracies: 20 Years after the Fall of Communism. Politics \& Policy 37(4): 661-666.

Stegmaier, Mary - Lewis-Beck, and Michael S. (2009): Learning the Economic Vote: Hungarian Forecast, 1998-2011. Politics \& Policy 37(4): 769-780.

Pop-Eleches, Grigore and Tucker, Joshua (2011): Communist Legacies, and Political Values and Behavior: A Theoretical Framework with an Application to Political Party Trust. Comparative Politics 43(4): 379-408.

Whitten, Guy D. and Palmer, Harvey D. (1999): Cross-national analysis of economic voting. Electoral Studies 18: 49-77.

Zielonka, Jan (2007): The Quality of Democracy after Joining the European Union. East European Politics and Societies 21(1): 162-180.

Andrea Fumarola is pursuing a PhD in Political Science at LUISS 'Guido Carli' in Rome with a dissertation on the political determinants of electoral accountability in Central and Eastern Europe. He hold a MA in Parliament and Public Policies in 2012 at LUISS and a MA in Mass Media and Politics at University of Bologna (Forli Campus) in 2011. From February 2016, he is visiting research fellow at University of Sydney within the framework of the Electoral Integrity Project, directed by prof. Pippa Norris, with a research project on the role of electoral integrity in influencing electoral accountability in emerging European democracies. E-mail: afumarola@luiss.it 